\title{
Changes in $\mathrm{A}_{2 \mathrm{~A}}$ adenosine receptor parameters in patients affected by bipolar disorders: Correlation with antipsychotic dosage and severity of illness
}

\author{
Maria Letizia Trincavelli*, Simona Daniele, Antonio Ciapparelli, Mario Catena Dell’Osso, \\ Gabriele Massimetti, Donatella Marazziti, Liliana Dell’Osso, Claudia Martini*
}

Department of Psychiatry, Neurobiology, Pharmacology and Biotechnology, University of Pisa, Pisa, Italy Email: ${ }^{*}$ cmartini@,farm.unipi.it, ${ }^{*}$ ltrincavelli@,farm.unipi.it

Received 21 November 2011; revised 25 November 2011; accepted 5 December 2011

\section{ABSTRACT}

Typical antipsychotics, potent $\mathrm{D}_{2}$ dopamine receptor antagonists, are the most commonly used drugs in the treatment of bipolar disorders. In the central nervous system, the discovery of antagonistic interactions between $A_{2 A}$ adenosine receptors and $D_{2}$ dopamine receptors suggests that the adenosine system may be involved in the pathogenesis of different psychiatric disorders and in the therapeutic effectiveness of antipsychotic drugs. Previously, we have demonstrated an increase in $A_{2 A}$ receptor expression and agonist affinity in platelets from psychotic patients treated with haloperidol. This result suggests that there is also a structural and functional interaction between $A_{2 A}$ and $D_{2}$ receptors in peripheral cells. In this work, we investigated the effect of different doses of typical drugs on $\mathrm{A}_{2 \mathrm{~A}}$ adenosine receptor binding and correlated these parameters with the severity of symptoms. We demonstrated, for the first time, that there was a strong correlation between $A_{2 A}$ receptor affinity constant values $(\mathrm{Kd})$ and drug doses in psychotic patients with a moderate severity of illness and moderate psychotic symptoms. The correlation was completely lost in patients with severe illness and severe psychotic symptoms. These results demonstrated that in platelets of patients affected by psychosis, typical antipsychotics modulated $\mathrm{A}_{2 \mathrm{~A}}$ receptor binding parameters; this regulation is dependent on the degree of $D_{2}$ receptor occupancy in relation to the severity of psychotic symptoms, suggesting $A_{2 A}$ receptors are a peripheral marker for individual therapy effectiveness.

Keywords: Bipolar Disorders; Human Platelets; $\mathrm{A}_{2 \mathrm{~A}}$ Adenosine Receptors; Typical Antipsychotics; Severity of Illness; $\mathrm{A}_{2 \mathrm{~A}} / \mathrm{D}_{2}$ Functional Interaction

${ }^{*}$ Corresponding author.

\section{INTRODUCTION}

Bipolar disorder (BD) is a psychiatric diagnosis that describes a category of mood disorders defined by the presence of one or more episodes of abnormally elevated energy levels, cognition, and mood with or without one or more depressive episodes. The elevated moods are clinically referred to as mania that can sometimes lead to such psychotic symptoms as delusions and hallucinations (DSM-IV-TR, American Psychiatric Association, 2000). Adenosine system has been involved in maniac symptoms and in particular in kindling phenomena that are a valuable model to explain the pathological activation, increase of energy and recurrence of maniac episodes [1]. The role of adenosine in the control of mood in BD stems from different lines of evidences: 1) during kindling phenomena adenosine is released and in several animal models it has been demonstrated that the use of adenosine agonists may have anti-kindling properties [2]; 2) caffeine, that is a non-selective antagonist for both $A_{1}$ and $A_{2 A}$ adenosine receptor (AR) subtypes, has a mania-like stimulant effects worsening the course of seasonal BD, causing a persistent state of arousal and an exacerbation of maniac symptoms [3-6]; 3) in BD an increase in purinergic turnover has been described [7] and the use of xantine-oxidase inhibitors as anti-maniac agents have been suggested $[8,9]$.

The involvement of adenosine in the control of maniac behaviour first arose based on its tight interaction with dopamine systems [10-13]. The functional and structural interaction between $\mathrm{A}_{2 \mathrm{~A}}$ ARs and $\mathrm{D}_{2}$ dopamine receptors ( $D_{2}$ DRs) have been yet demonstrated since several years. By the means of different methodological approaches, such as co-immunoprecipitation, FRET/BRET [14,15], biochemical and microdyalisis techniques, the existence of $A_{2 A} A R-D_{2}$ DR heterodimers and higher order receptor heteromers, called receptor mosaics, in the striatopallidal GABA neurons $[13,16]$ has been demonstrated. These heteromers control the excitability of GABAergic neu- 
rons counteracting $\mathrm{D}_{2}$ DR signalling at multiple effectors [17].

The functional cross-talk between adenosine and dopamine receptors may have important pathophysiological and therapeutic implications in psychiatric diseases associated to dopaminergic dysfunction. The dissection of the molecular mechanisms underlying the regulation of $A_{2 A}$ AR expression and functioning represent a crucial aspect in further clarifying the pathophysiological role of adenosine in psychiatric diseases and should be taken into account (1) in developing new drugs as well as (2) in preventing possible side effects of drugs indirectly modulating the adenosine system.

Recently, we have demonstrated both in transfected cell lines [18] and in platelets of patients with BD [19], that typical antipsychotic drugs, acting as $\mathrm{D}_{2} \mathrm{DR}$ antagonists, modulated $\mathrm{A}_{2 \mathrm{~A}} \mathrm{AR}$ functional responsiveness, suggesting $\mathrm{A}_{2 \mathrm{~A}} \mathrm{AR}$ agonists as a possible target, in association with $\mathrm{D}_{2}$ antagonists, in the therapeutic treatment of $\mathrm{BD}$. Based on these results we evaluated the effect of different doses of typical drugs on $\mathrm{A}_{2 \mathrm{~A}}$ AR binding parameters in order to identify a possible correlation between the modulation of $\mathrm{A}_{2 \mathrm{~A}}$ receptor activity and the degree of $\mathrm{D}_{2}$ receptor blockade also in relation to the severity of illness and the effectiveness of individual therapy. These results allowed us to identify $A_{2 A} A R$ as a peripheral marker of $D_{2}$ DR occupancy and of the therapeutic effectiveness of typical drugs.

\section{METHODS}

\subsection{Study Sample}

Twenty-four patients affected by BD with psychotic symptoms were recruited from the Department of Psychiatry, University of Pisa, Pisa, Italy. All patients were treated with typical antipsychotic drugs for at least six months. The patients received doses of antipsychotic therapy between 20 to $900 \mathrm{mg} /$ day equivalent of chlorpromazine. The patients met the DSM-IV-TR diagnostic criteria (American Psychiatric Association, 2000) for BD and were between the ages of 18 and 65 years. Subjects who were pregnant or had unstable medical conditions were excluded. All of the patients gave their informed consent to participate in the study. The study was approved by the local Ethical Committee in accordance with the Declaration of Helsinki (1996), and with the Guidelines of the Good Clinical Practice (1995). The control group included 32 healthy volunteers with no history of mental disorders, alcoholism or drug abuse, and with no medical illnesses, as determined by clinical interviews.

\subsection{Clinical Assessments}

The severity of illness of each patient was evaluated us- ing the Clinical Global Impression Scale (CGI) [20]. The level of symptoms during the week preceding discharge was assessed using the 18-item version of the brief psychiatric rating scale (BPRS) [21]. Clinical information was collected directly from the patients and from at least one close relative as a co-informant. Medical health was documented by reviewing the medical history and through a physical examination. Three resident psychiatrists with clinical research experience performed the diagnostic and psychopathological assessments. Two senior psychiatrists (LDO and AC) who were not directly involved in the assessments confirmed the diagnoses.

\subsection{Materials}

Labelled and unlabelled-(2-[7-amino-2-(2-furyl) [1,2,4] triazolo [2,3-a] [1,3,5] triazine-5-yl-amino]ethyl)phenol $\left(\mathrm{ZM}_{241385}\right)$ were from Tocris Cookson (UK). All other chemicals were supplied by standard commercial sources.

\subsection{Platelet Isolation}

Blood samples $(30 \mathrm{ml})$ from healthy volunteers and patients were collected in sodium citrate anticoagulant (1:6 dilution, $2.2 \%$ sodium-citrate, and $1.2 \%$ citric acid), and platelet-rich plasma (PRP) was obtained by low-speed centrifugation at $200 \times \mathrm{g}$ for $20 \mathrm{~min}$ at room temperature. The PRP was then centrifuged at $2000 \times \mathrm{g}$ for $15 \mathrm{~min}$ at room temperature to precipitate platelets. The platelets were then washed once in $40-50 \mathrm{ml}$ of an ice-cold physiological saline solution (isotonic, $0.9 \% \mathrm{NaCl}$ ) and pelleted at $15,000 \times \mathrm{g}$ for $15 \mathrm{~min}$ at $4^{\circ} \mathrm{C}$.

\subsection{Preparation of Platelet Membrane Suspensions}

Platelet membranes were prepared from 32 healthy volunteers and 24 patients as previously described $[19,22]$. Briefly, platelets were suspended in Tris-buffer A (50 $\mathrm{mM}$ Tris- $\mathrm{HCl}, 20 \mathrm{mM}$ EDTA, $150 \mathrm{mM} \mathrm{NaCl}$; $\mathrm{pH} 7.4$ at $4^{\circ} \mathrm{C}$ ) and centrifuged at $17,500 \times \mathrm{g}$ for $15 \mathrm{~min}$ at $25^{\circ} \mathrm{C}$. The washed platelets were suspended in ice-cold hypotonic buffer B ( $5 \mathrm{mM}$ Tris-HCl, and $5 \mathrm{mM}$ EDTA, pH 7.4 at $4^{\circ} \mathrm{C}$ ) and homogenized with a Polytron for $30 \mathrm{sec}-$ ond before centrifugation at $35,000 \times \mathrm{g}$ for $15 \mathrm{~min}$ at $4^{\circ} \mathrm{C}$. The resulting pellet was re-suspended in membrane buffer (50 mM Tris-HCl, pH 7.4, $0.8 \mathrm{mM}$ EDTA, 0.16 $\mathrm{mg} / \mathrm{ml}$ benzamidine, $0.2 \mathrm{mg} / \mathrm{ml}$ bacitracine, and 0.02 $\mathrm{mg} / \mathrm{ml}$ tripsin inhibitor), rapidly frozen in liquid nitrogen and stored at $-80^{\circ} \mathrm{C}$ until it was used.

\section{6. $\left[{ }^{3} \mathrm{H}\right] \mathrm{ZM}_{241385}$ Binding Assay}

$\mathrm{A}_{2 \mathrm{~A}} \mathrm{AR}$ equilibrium binding parameters were determined by saturation binding studies using the selective $A_{2 A} A R$ antagonist $\left[{ }^{3} \mathrm{H}\right] \mathrm{ZM}_{241385}$ [19]. Saturation binding experi- 
ments were performed incubating platelet membranes $(50 \mu \mathrm{g})$ in binding buffer $(50 \mathrm{mM}$ Tris- $\mathrm{HCl}$, and $0.8 \mathrm{mM}$ EDTA, $\mathrm{pH}$ 7.4) in the presence of five different $\left[{ }^{3} \mathrm{H}\right]$ $\mathrm{ZM}_{241385}$ concentrations ranging from 0.2 to $10 \mathrm{nM}$ at $4^{\circ} \mathrm{C}$ for $1 \mathrm{~h}$. Non-specific binding was determined in the presence of $1 \mu \mathrm{M}$ unlabelled $\mathrm{ZM}_{241385}$.

\subsection{Data Analysis and Statistic}

Scatchard analysis of radioligand saturation binding data was performed using the non-linear multipurpose curvefitting computer program Graph-Pad Prism (GraphPad, San Diego, CA).

Since $\mathrm{K}_{\mathrm{d}}$ and $\mathrm{B}_{\max }$ values are not normally distributed, all of the statistical analyses were conducted on their logarithmic transformations. To compare the mean levels of these variables in control vs. patient independent samples, the Student's t test was utilized. A p-value of $<0.05$ was judged as statistically significant. All data are presented as mean \pm standard deviation.

Linear regression analyses and bivariate Pearson's correlation coefficients were performed in order to evaluate the relationships between the $\mathrm{K}_{\mathrm{d}}$ values and the chlorpromazine equivalent of drug in relation to patient characteristics (severity of illness, total PBRS and factor scores).

All of the analyses were carried out using SPSS, version 14.0 , by means of personal computers.

\section{RESULTS}

\subsection{Clinical Characteristics of BD Patients}

No gender differences were found between the control (male: $81.3 \%$ ) and BD patient (male: $83.3 \%$ ) groups.

The mean BPRS total scores \pm SD by the patients was $48.46 \pm 15.77$, while the score of each factor was the following: anxiety-depression $(\mathrm{ANDP})=3.27 \pm 1.28$, anergia $($ ANER $)=1.50 \pm 0.67$, thought disturbance $($ THOT $)$ $=2.52 \pm 1.73$, activation $(\mathrm{ACTV})=3.54 \pm 1.72$, and hostile suspiciousness $(\mathrm{HOST})=2.80 \pm 1.67$.

\section{2. $A_{2 A}$ AR Equilibrium Binding Parameters in Platelets from BD Patients under Treatment with Typical Antipsychotics}

The $A_{2 A}$ AR equilibrium binding parameters were evaluated in human platelets from healthy volunteers, $(\mathrm{N}=32)$ and patients with $\mathrm{BD}(\mathrm{N}=24)$ under chronic treatment with typical antipsychotics. Scatchard analysis of the $\left[{ }^{3} \mathrm{H}\right]$ $\mathrm{ZM}_{241385}$ saturation binding data demonstrated that in control platelets, the radioligand bound a homogenous population of binding sites with an affinity constant value $\left(\mathrm{K}_{\mathrm{d}}\right)$ and a maximum density of binding sites $\left(\mathrm{B}_{\max }\right)$ of $4.59 \pm 1.79 \mathrm{nM}$ (Figure 1 (a)) and $244.97 \pm 76.93$ $\mathrm{fmol} / \mathrm{mg}$ proteins (Figure 1 (b)), respectively. To evalu- ate the effect of antipsychotic treatment on the $A_{2 A} A R$ binding parameters, $\left[{ }^{3} \mathrm{H}\right] \mathrm{ZM}_{241385}$ saturation analysis was performed on platelet membranes obtained from $24 \mathrm{BD}$ patients treated with typical antipsychotic drugs for at least six months. In BD patients, $\left[{ }^{3} \mathrm{H}\right] \mathrm{ZM}_{241385}$ bound a homogeneous population of binding sites with a $\mathrm{K}_{\mathrm{d}}$ and $\mathrm{B}_{\max }$ value of $1.90 \pm 1.39 \mathrm{nM}$ (Figure 1 (a)) and 270.22 $\pm 150.94 \mathrm{fmol} / \mathrm{mg}$ of proteins (Figure 1 (b)), respectively.

As shown in Table 1, a significant difference in the $\mathrm{K}_{\mathrm{d}}$ values between the control and patient groups was observed. On the contrary, in BD patients treated with typical antipsychotics, no significant differences in the $B_{\max }$ value were observed with respect to controls.

To evaluate if the variability in the $K_{d}$ of the $A_{2 A} A R$ parameters observed in the BD patients was related to the dosage of the administered typical antipsychotic, statistical correlation analyses were performed. Considering the whole group of patients, no significant correlations were detected between the $K_{d}$ values and the equivalent of chlorpromazine, and between the $\mathrm{K}_{\mathrm{d}}$ and the clinical

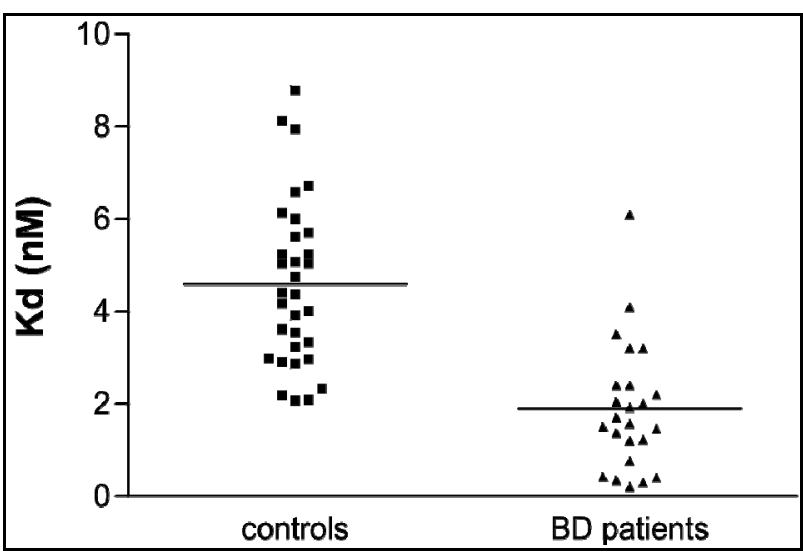

(a)

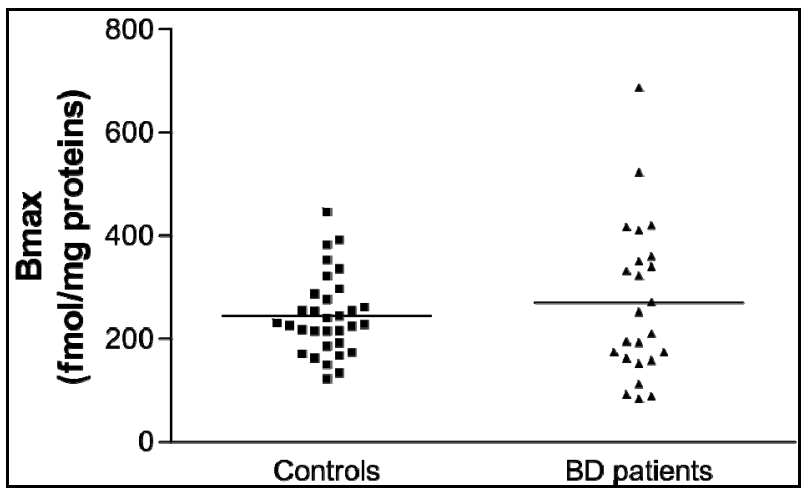

(b)

Figure 1. The figures display individual results for the $\left[{ }^{3} \mathrm{H}\right]$ $\mathrm{ZM}_{241385} \mathrm{~K}_{\mathrm{d}}(\mathrm{A})$ and $\mathrm{B}_{\max }(\mathrm{B})$ values obtained in platelets from healthy volunteers (controls; $\mathrm{N}=32$ ) and BD patients $(\mathrm{N}=24)$. The horizontal lines represent the mean values \pm SEM from healthy volunteers and patients. 
Table 1. Comparison between the mean levels of $\mathrm{Ln} \mathrm{K}_{\mathrm{d}}$ and $\mathrm{Ln}$ $\mathrm{B}_{\max }$ in the controls (a) vs BD patients; (b) Student's t test.

\begin{tabular}{cccc}
\hline $\begin{array}{c}\mathbf{A}_{2 \mathrm{~A}} \text { binding } \\
\text { parameters }\end{array}$ & Mean \pm SD & t & Sig. (2-tailed) \\
\hline Ln K $\mathbf{K}_{\mathbf{d}}$ & (a) $1.45 \pm 0.40$ & 6.321 & 0.000 \\
& (b) $0.33 \pm 0.89$ & & \\
Ln B $_{\max }$ & (a) $5.45 \pm 0.31$ & 0.066 & 0.948 \\
& (b) $5.45 \pm 0.58$ & & \\
\hline
\end{tabular}

patient characteristics (CGI, total BPRS scores and factor scores).

Nevertheless, after subdividing the patients into two groups on the basis of the severity of illness (CGI $\leq 4$ : moderate ill; CGI $>4$ : severe ill), a significant negative correlation between the $A_{2 A} A R K_{d}$ values and the equivalent of chlorpromazine dose was detected only in the group of patients with moderate illness (see Table 2).

Moreover, a negative correlation between the $\mathrm{A}_{2 \mathrm{~A}} \mathrm{AR}$ $K_{d}$ values and the equivalent of chlorpromazine dose was detected after subdividing the patients into two groups on the basis of the median of total BPRS scores and the
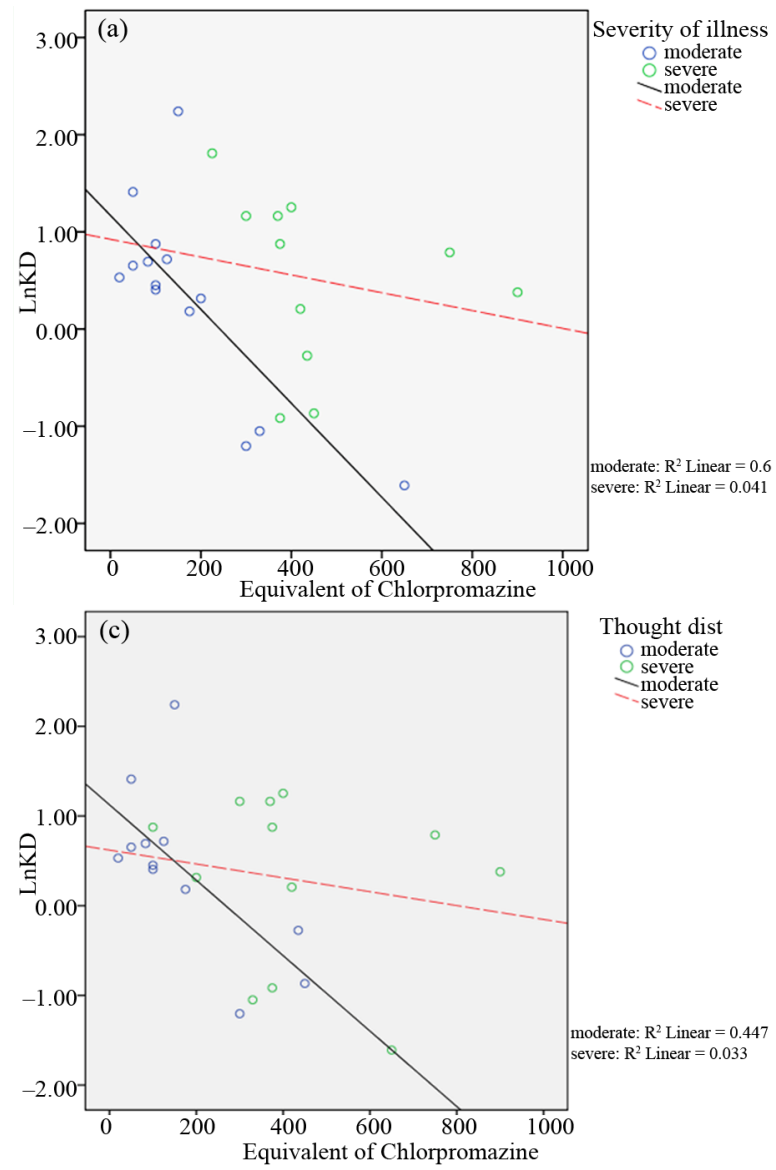

Figure 2. Scattergrams obtained from bivariate Pearson's correlation between $A_{2 A} A R K_{d}$ values and the equivalent of chlorpromazine in the two groups of BD patients with moderate and severe psychotic symptoms. Patient classification was performed on the basis of CGI scores ( 4 = moderate; $>4=$ severe; panel a), the median of total BPRS scores (median $=43.50$; panel $b$ ), the median of THOT factor scores $($ median $=1.63$; panel $\mathrm{c})$ and the median of HOS factor scores (median = 2.33; panel d).

Table 2. The Bivariate Pearson's correlation between the $A_{2 A}$ $\mathrm{AR} \mathrm{K}_{\mathrm{d}}$ values and the equivalent of chlorpromazine in two groups of $\mathrm{BD}$ patients with moderate and severe psychotic disturbance, respectively.

\begin{tabular}{cll}
\hline & Moderate illness & Severe illness \\
\hline CGI & $\mathrm{R}=-0.755$ & $\mathrm{R}=-0.202$ \\
& $\mathrm{p}=0.001$ & $\mathrm{p}=0.551$ \\
$\mathrm{n}=14$ & $\mathrm{n}=11$ \\
Total BPRS & $\mathrm{R}=-0.794$ & $\mathrm{R}=-0.075$ \\
& $\mathrm{p}=0.002$ & $\mathrm{p}=0.817$ \\
THOT & $\mathrm{n}=12$ & $\mathrm{n}=12$ \\
& $\mathrm{R}=-0.669$ & $\mathrm{R}=-0.182$ \\
& $\mathrm{p}=0.017$ & $\mathrm{p}=0.570$ \\
OST & $\mathrm{n}=12$ & $\mathrm{n}=12$ \\
& $\mathrm{R}=-0.589$ & $\mathrm{R}=-0.219$ \\
& $\mathrm{p}=0.057$ & $\mathrm{p}=0.472$ \\
& $\mathrm{n}=14$ & $\mathrm{n}=13$ \\
\hline
\end{tabular}

median of factor III (THOT) and factor V (OST) BPRS scores (see Table 2).

In the relative scattergrams (Figure 2), we can observe the different slopes of the straight-line for moderate and severe psychotic disturbances.
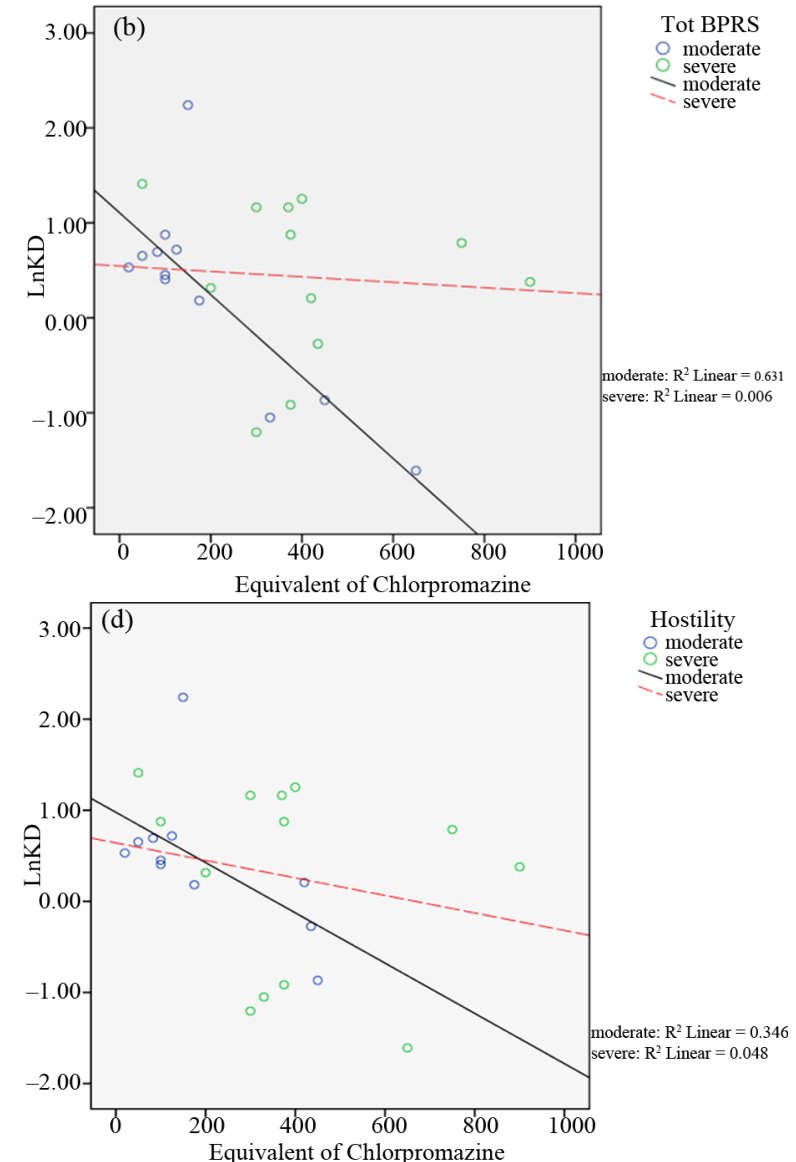

Copyright (C) 2012 SciRes.

OPEN ACCESS 


\section{DISCUSSION}

In this work, we demonstrated that typical antipsychotic drugs, acting as $D_{2}$ DR antagonists, selectively affected the $A_{2 A} A R$ affinity constant value in human platelets of BD patients under chronic treatment with these drugs. The main finding of these data is that administered typical drugs induced a reduction in $\mathrm{A}_{2 \mathrm{~A}} \mathrm{AR} \mathrm{K}_{\mathrm{d}}$ values in a dose-dependent-manner, demonstrating the existence of a correlation between $\mathrm{D}_{2}$ DR occupancy and $\mathrm{A}_{2 \mathrm{~A}}$ AR regulation induced by the dopamine system.

Although blocking of the $\mathrm{D}_{2}$ DR remains central to the therapeutic properties of antipsychotics, these drugs appear to act by mechanisms involving other neurotransmitter systems, including serotonin and adenosine [23, 24]. The involvement of the adenosine system and of the $\mathrm{A}_{2 \mathrm{~A}}$ ARs in psychiatric diseases [12,25-28], including $\mathrm{BD}$ [3-6] has been demonstrated and it has been related to a functional cross-talk with the dopaminergic system, in particular with the $\mathrm{D}_{2}$ DRs. $\mathrm{D}_{2}$ DRs are highly expressed in striatopallidal neurons, where they co-localize with adenosine $A_{2 \mathrm{~A}}$ ARs [29], presumably forming functional heterodimers in which adenosine and dopamine receptors mutually regulate their responses [14,15,30-33].

In a previous work [19], we demonstrated that typical antipsychotics, but not atypical ones, induced an up-regulation of $\mathrm{A}_{2 \mathrm{~A}} \mathrm{AR}$ expression and functional response in the platelets of $\mathrm{BD}$ patients. We demonstrated in particular that: 1) $\mathrm{A}_{2 \mathrm{~A}}$ and $\mathrm{D}_{2}$ receptors are co-expressed in platelets and interact to form functional heterodimers in which the response of one receptor may be modulated by the selective block of the other, and 2) typical and atypical antipsychotics, which show a different mechanism of action at the molecular level, may differently control the functional regulation of $\mathrm{A}_{2 \mathrm{~A}} \mathrm{AR}$. A crucial point that distinguishes different classes of antipsychotics is the degree of dopamine $\mathrm{D}_{2}$ DR occupancy and the kinetics of drug receptor-dissociation, on which the drug response and some unpleasant side effects depend. Typical antipsychotics, such us haloperidol, have a high $\mathrm{D}_{2}$ DR occupancy and slow dissociation rates that are likely connected to the extrapyramidal side effects $[34,35]$ of these drugs.

On the contrary, clozapine, an atypical drug, shows a much lower occupancy and a fast dissociation rate; this may explain its freedom from extrapyramidal side effects $[36,37]$. These differences in the activity profiles of the two antipsychotic classes may be at the root of the specific effects observed in the $\mathrm{A}_{2 \mathrm{~A}}$ regulatory mechanisms.

In order to investigate whether $A_{2 A} A R$ could be used as a marker of $\mathrm{D}_{2}$ receptor occupancy in relation to therapy efficacy, we aimed to evaluate the regulation of $\mathrm{A}_{2 \mathrm{~A}}$ AR that is induced by different doses of typical drugs. The study was performed by assessing $\mathrm{A}_{2 \mathrm{~A}}$ AR equilibrium-binding parameters in the platelets of patients af- fected by bipolar disorders, all under the treatment of typical drugs for at least six months.

The results confirmed that in BD patients, a reduction in $A_{2 A} A R K_{d}$ values had occurred, demonstrating that the typical antipsychotics affected $\mathrm{A}_{2 \mathrm{~A}}$ AR ligand affinity by increasing its functional activity. On the contrary, with respect to the previous work, increasing the number of patient groups resulted in no significant differences in the maximal density of $A_{2 A}$ AR binding sites. These results suggest that the block of the $D_{2}$ receptor mainly affects the $A_{2 A} A R$ conformational state rather than its total number. These data have been also confirmed in a model of CHO cells co-transfected with both $\mathrm{A}_{2 \mathrm{~A}}$ and $\mathrm{D}_{2}$ receptors [18]. Statistical analyses were also performed in order to evaluate the existence of a correlation between the changes in the $A_{2 A} K_{d}$ values and the drug doses, expressed as an equivalent of chlorpromazine. Interestingly we demonstrated that in the BD patient groups that there was no statistically significant correlation between the $A_{2 A} A R K_{d}$ values and the equivalent of chlorpromazine. Additionally, when the patients were grouped on the basis of severity of illness as "moderate illness" (CGI value $\leq 4$ ) and "severe illness" (CGI > 4), a significant negative correlation between the two parameters was detected only in the moderate illness group of the patients. On the other hand, this correlation was lost in the group of patients with a high severity of illness. Moreover, the same results were obtained when the patients were grouped on the basis of the median of total BPRS scores, and the median of two BPRS factor scores, and in particular the factor III (Thought disturbance) and the factor V (Hostile suspiciousness). These BPRS factors are the main representative of psychotic symptoms. In detail, factor III includes four items: conceptual disorganization, grandiosity, hallucinatory behaviour and unusual thought content. Factor $\mathrm{V}$ includes three items: hostility, suspiciousness and uncooperativeness, all symptoms of psychotic behaviour. Our results can then suggest that the regulation of $\mathrm{A}_{2 \mathrm{~A}} \mathrm{AR}$ in response to antipsychotics may be a new marker for monitoring therapy efficacy, and particularly in relation to psychotic symptoms. In addition, the results suggest that the degree of the $\mathrm{D}_{2}$ receptor block may have an important role in the $A_{2 A}$ AR regulatory mechanisms only in responder patients with respect to non-responder patients. The lack of $A_{2 \mathrm{~A}}-\mathrm{D}_{2}$ cross-regulation in non-responder patients could be explained by the idea that in non-responder patients an alteration of the dopaminergic system response had occurred. This hypothesis may be supported by the primary persistence of negative symptoms in these patients. Furthermore, it is also likely that the impairment of the responsiveness of the dopamine receptor caused, in turn, an alteration in the cross-regulation between adenosine and dopamine receptors. To dissect this issue a direct monitoring of $\mathrm{D}_{2}$ receptor occupancy and of $\mathrm{D}_{2}$ receptor 
functional responsiveness in non-responder vs responder patients should be evaluated. Unfortunately, the evaluation of receptor $\mathrm{D}_{2}$ occupancy is not detectable by radioligand binding in peripheral human blood cells that express the receptors at low levels. In fact, all of the studies aimed to assess the degree of $\mathrm{D}_{2}$ receptor occupancy following antipsychotic administration have been performed in animal models [38] or in the human brain using PET/SPECT technology [39-42]. In this context, since $\mathrm{D}_{2}$ receptor occupancy has been identified as an important aspect for individual therapeutic responsiveness and for the appearance of side effects, the $A_{2 A} A R$ binding parameters, which are quantifiable in human platelets, may represent an indirect index to evaluate the degree of $\mathrm{D}_{2}$ receptor occupancy for individual patients. This may be a useful means to seek therapy for maximum effectiveness and fewer side effects.

\section{ACKNOWLEDGEMENTS}

This work was supported by a grant funded by the Monte dei Paschi di Siena Foundation. The Foundation had no further role in the study design, collection, analysis or interpretation of the data, the writing of the report or the decision to submit the paper for publication.

We thank the PhD student Anna Panighini for the supporting in data elaboration.

\section{REFERENCES}

[1] Post, R.M. (2007) Kindling and sensitization as models for affective episode recurrence, cyclicity, and tolerance phenomena. Neuroscience Biobehavioral Review, 31, 858-873. doi:10.1016/j.neubiorev.2007.04.003

[2] Simonato, M., Varani, K., Muzzolini, A., Bianchi, C., Beani, L. and Borea, P.A. (1994) Adenosine A1 receptors in the rat brain in the kindling model of epilepsy. European Journal of Pharmacology, 265, 121-124. doi:10.1016/0014-2999(94)90421-9

[3] Whitcomb, K., Lupica, C.R., Rosen, J.B. and Berman, R.F. (1990) Adenosine involvement in postictal events in amygdala-kindled rats. Epilepsy Research, 6, 171-179. doi:10.1016/0920-1211(90)90070-C

[4] Kulkarni, C., David, J. and Joseph, T. (1997) Influence of adenosine, dipyridamole, adenosine antagonists and antiepileptic drugs on EEG after discharge following cortical stimulation. Indian Journal Experimental Biology, 35, 342-347.

[5] Kilzieh, N. and Akiskal, H.S. (1999) Rapid-cycling bipolar disorder. An overview of research and clinical experience. Psychiatric Clinic North America, 22, 585-607. doi:10.1016/S0193-953X(05)70097-6

[6] Tondo, L. and Rudas, N. (1991) The course of a seasonal bipolar disorder influenced by caffeine. Journal of Affective Disorders, 22, 249-251. doi:10.1016/0165-0327(91)90071-Y

[7] Brooks, S.C., Linn, J.J. and Disney, N. (1978) Serotonin, folic acid, and uric acid metabolism in the diagnosis of neuropsychiatric disorders. Biological Psychiatry, 13, 671684.

[8] Machado-Vieira, R., Lara, D.R., Souza, D.O. and Kapczinski, F. (2001) Therapeutic efficacy of allopurinol in mania associated with hyperuricemia. Journal of Clinical Psychopharmacology, 21, 621-622. doi:10.1097/00004714-200112000-00017

[9] Akhondzadeh, S., Milajerdi, M.R., Amini, H. and Tehrani-Doost, M. (2006) Allopurinol as an adjunct to lithiumand haloperidol for treatment of patients with acutemania: A double-blind, randomized, placebo-controlled trial. Bipolar Disorders, 8, 485-489. doi:10.1111/j.1399-5618.2006.00363.x

[10] Ferré, S., Ciruela, F., Canals, M., Marcellino, D., Burgueno, J., Casadó, V., Hillion, J., Torvinen, M., Fanelli, F., Benedetti, P.P., Goldberg, S.R., Bouvier, M., Fuxe, K., Agnati, L.F., Lluis, C., Franco, R. and Woods, A. (2004) Adenosine $\mathrm{A}_{2 \mathrm{~A}}$-dopamine $\mathrm{D}_{2}$ receptor-receptor heteromers. Targets for neuro-psychiatric disorders. Parkinsonism \& Related Disorders, 10, 265-271. doi:10.1016/j.parkreldis.2004.02.014

[11] Cunha, R.A., Ferré, S., Vaugeois, J.M. and Chen, J.F. (2008) Potential therapeutic interest of adenosine $A_{2 A}$ receptors in psychiatric disorders. Current Pharmaceutical Design, 14, 1512-1524. doi: $10.2174 / 138161208784480090$

[12] Shen, H.Y. and Chen, J.F. (2009) Adenosine $A_{2 A}$ receptors in psychopharmacology: Modulators of behaviour, mood and cognition. Current Neuropharmacology, 7, 195206. doi:10.2174/157015909789152191

[13] Fuxe, K., Marcellino, D., Borroto-Escuela, D.O., Guescini, M., Fernández-Dueñas, V., Tanganelli, S., Rivera, A., Ciruela, F. and Agnati, L.F. (2010) Adenosine-do-pamine interactions in the pathophysiology and treatment of CNS disorders. CNS Neuroscience \& Therapeutics, 16, e18-e42. doi:10.1111/j.1755-5949.2009.00126.x

[14] Canals, M., Marcellino, D., Fanelli, F., Ciruela, F., de Benedetti, P., Goldberg, S.R., Neve, K., Fuxe, K., Agnati, L.F., Woods, A.S., Ferré, S., Lluis, C., Bouvier, M. and Franco, R. (2003) Adenosine $A_{2 A}$-dopamine $D_{2}$ receptor-receptor heteromerization: Qualitative and quantitative assessment by fluorescence and bioluminescence energy transfer. Journal of Biological Chemistry, 278 46741-46749. doi:10.1074/jbc.M306451200

[15] Kamiya, T., Saitoh, O., Yoshioka, K. and Nakata, H. (2003) Oligomerization of adenosine $\mathrm{A}_{2 \mathrm{~A}}$ and dopamine $\mathrm{D}_{2}$ receptors in living cells. Biochemical and Biophysical Research Communication, 306, 544-549. doi:10.1016/S0006-291X(03)00991-4

[16] Cabello, N., Gandía, J., Bertarelli, D.C., Watanabe, M., Lluís, C., Franco, R., Ferré, S., Luján, R. and Ciruela, F. (2009) Metabotropic glutamate type 5, dopamine $\mathrm{D}_{2}$ and adenosine $\mathrm{A}_{2 \mathrm{~A}}$ receptors form higher-order oligomers in living cells. Journal of Neurochemistry, 109, 1497-1507. doi:10.1111/j.1471-4159.2009.06078.x

[17] Fuxe, K., Ferré, S., Genedani, S., Franco, R. and Agnati, L.F. (2007) Adenosine receptor-dopamine receptor interactions in the basal ganglia and their relevance for brain function. Physiology \& Behaviour, 92, 210-217. 
doi:10.1016/j.physbeh.2007.05.034

[18] Trincavelli, M.L., Cuboni, S., Catena Dell'Osso, M., Maggio, R., Klotz, K.N., Novi, F., Panighini, A., Daniele, S. and Martini, C. (2010) Receptor crosstalk: Haloperidol treatment enhances $\mathrm{A}_{2 \mathrm{~A}}$ adenosine receptor functioning in a transfected cell model. Purinergic Signalling, 6, 373381. doi:10.1007/s11302-010-9201-Z

[19] Martini, C., Tuscano, D., Trincavelli, M.L., Cerrai, E., Bianchi, M., Ciapparelli, A., Lucioni, A., Novelli, L., Catena, M., Lucacchini, A., Cassano, G.B. and Dell'Osso, L. (2006) Upregulation of $\mathrm{A}_{2 \mathrm{~A}}$ adenosine receptors in platelets from patients affected by bipolar disorders under treatment with typical antipsychotics. Journal of Psychiatric Research, 40, 81-88.

doi:10.1016/i.jpsychires.2004.12.008

[20] Guy, W. (1976) ECDEU assessment manual for psychopharmacology, revised 1976. National Institutes of Mental Health, Rockville.

[21] Overall, J.E. and Gorham, D.R. (1962) The brief psychiatric rating scale. Psychological Reports, 10, 799-812. doi:10.2466/PR0.10.3.799-812

[22] Varani, K., Gessi, S., Dalpiaz, A. and Borea, P.A. (1996) Pharmacological and biochemical characterization of purified $\mathrm{A}_{2 \mathrm{~A}}$ adenosine receptors in human platelet membranes by $\left[{ }^{3} \mathrm{H}\right]$-CGS 21680 binding. British Journal of Pharmacology, 117, 1693-1701.

[23] Lara, D.R., Dall'Igna, O.P., Ghisolfi, E.S. and Brunstein, M.G. (2006) Involvement of adenosine in the neurobiology of schizophrenia and its therapeutic implications. Progress in Neuro-psychopharmacology \& Biological Psychiatry, 30, 617-629. doi:10.1016/j.pnpbp.2006.02.002

[24] Lara, D.R. and Souza, D.O. (2000) Schizophrenia: A purinergic hypothesis. Medical Hypotheses, 54, 157-166. doi:10.1054/mehy.1999.0003

[25] Parsons, B., Togasaki, D.M., Kassir, S. and Przedborski, S. (1995) Neuroleptics upregulate adenosine $A_{2 A}$ receptors in rat striatum: Implications for the mechanism and the treatment of tardive dyskinesia. Journal of Neurochemistry, 65, 2057-2064. doi:10.1046/j.1471-4159.1995.65052057.x

[26] Kurumaji, A. and Toru, M. (1998) An increase in $\left[{ }^{3} \mathrm{H}\right]$ CGS21680 binding in the striatum of postmortem brains of chronic schizophrenics. Brain Research, 808, 320-323. doi:10.1016/S0006-8993(98)00840-3

[27] Deckert, J., Brenner, M., Durany, N., Zöchling, R., Paulus, W., Ransmayr, G., Tatschner, T., Danielczyk, W., Jellinger, K. and Riederer, P. (2003) Up-regulation of striatal adenosine $\mathrm{A}_{2 \mathrm{~A}}$ receptors in schizophrenia. Neuroreport, 14, 313-316. doi:10.1097/00001756-200303030-00003

[28] Urigüen, L., García-Fuster, M.J., Callado, L.F., Morentin, B., La Harpe, R., Casadó, V., Lluis, C., Franco, R., García-Sevilla, J.A. and Meana, J.J. (2009) Immunodensity and mRNA expression of $\mathrm{A}_{2 \mathrm{~A}}$ adenosine, $\mathrm{D}_{2}$ dopamine, and $\mathrm{CB}_{1}$ cannabinoid receptors in postmortem frontal cortex of subjects with schizophrenia: Effect of antipsychotic treatment. Psychopharmacology (Berl), 206, 313324. doi:10.1007/s00213-009-1608-2
[29] Fink, J.S., Weaver, D.R., Rivkees, S.A., Peterfreund, R.A., Pollack, A.E., Adler, E.M. and Reppert, S.M. (1992) Molecular cloning of the rat $\mathrm{A}_{2}$ adenosine receptor: Selective co-expression with $\mathrm{D}_{2}$ dopamine receptors in rat striatum. Brain Research Molecular Brain Research, 14, 186-195. doi:10.1016/0169-328X(92)90173-9

[30] Tsai, S.J. (2005) Adenosine $A_{2 A}$ receptor/dopamine $D_{2}$ receptor hetero-oligomerization: A hypothesis that may explain behavioral sensitization to psychostimulants and schizophrenia. Medical Hypotheses, 64, 197-200. doi:10.1016/j.mehy.2004.04.018

[31] Genedani, S., Guidolin, D., Leo, G., Filaferro, M., Torvinen, M., Woods, A.S., Fuxe, K., Ferré, S. and Agnati, L.F. (2005) Computer-assisted image analysis of caveolin-1 involvement in the internalization process of adenosine $\mathrm{A}_{2 \mathrm{~A}}$-dopamine $\mathrm{D}_{2}$ receptor heterodimers. Journal of Molecular Neuroscience, 26, 177-184.

doi:10.1385/JMN:26:2-3:177

[32] Navarro, G., Carriba, P., Gandía, J., Ciruela, F., Casadó, V., Cortés, A., Mallol, J., Canela, E.I., Lluis, C. and Franco, R. (2008) Detection of heteromers formed by cannabinoid $\mathrm{CB}_{1}$, dopamine $\mathrm{D}_{2}$, and adenosine $\mathrm{A}_{2 \mathrm{~A}}$ G-protein-coupled receptors by combining bimolecular fluorescence complementation and bioluminescence energy transfer. Scientific World Journal, 8, 1088-1097. doi:10.1100/tsw.2008.136

[33] Vidi, P.A., Chemel, B.R., Hu, C.D. and Watts, V.J. (2008) Ligand-dependent oligomerization of dopamine $\mathrm{D}_{2}$ and adenosine $\mathrm{A}_{2 \mathrm{~A}}$ receptors in living neuronal cells. Molecular Pharmacology, 74, 544-551. doi: $10.1124 / \mathrm{mol} .108 .047472$

[34] Farde, L., Nordström, A.L., Wiesel, F.A., Pauli, S., Halldin, C. and Sedvall, G. (1992) Positron emission tomographic analysis of central $\mathrm{D}_{1}$ and $\mathrm{D}_{2}$ dopamine receptor occupancy in patients treated with classical neuroleptics and clozapine. Relation to extrapyramidal side effects. Archives of General Psychiatry, 49, 538-544. doi:10.1001/archpsyc.1992.01820070032005

[35] Nordström, A.L., Farde, L., Wiesel, F.A., Forslund, K., Pauli, S., Halldin, C. and Uppfeldt, G. (1993) Central $\mathrm{D}_{2}$-dopamine receptor occupancy in relation to antipsychotic drug effects: A double-blind PET study of schizophrenic patients. Biological Psychiatry, 33, 227-235. doi:10.1016/0006-3223(93)90288-O

[36] Kessler, R.M., Ansari, M.S., Riccardi, P., Li, R., Jayathilake, K., Dawant, B. and Meltzer, H.Y. (2006) Occupancy of striatal and extrastriatal dopamine $\mathrm{D}_{2}$ receptors by clozapine and quetiapine. Neuropsychopharmacology, 31, 1991-2001. doi:10.1038/sj.npp.1301108

[37] Catafau, A.M., Penengo, M.M., Nucci, G., Bullich, S., Corripio, I., Parellada, E., García-Ribera, C., Gomeni, R. and Merlo-Pich, E. (2008) Pharmacokinetics and timecourse of $\mathrm{D}_{2}$ receptor occupancy induced by atypical antipsychotics in stabilized schizophrenic patients. Journal of Psychopharmacology, 22, 882-894. doi: $10.1177 / 0269881107083810$

[38] Assié, M.B., Dominguez, H., Consul-Denjean, N. and Newman-Tancredi, A. (2006) In vivo occupancy of dopamine $D_{2}$ receptors by antipsychotic drugs and novel compounds in the mouse striatum and olfactory tubercles. 
Naunyn-Schmiedeberg's Archives of Pharmacology, 373, 441-450. doi:10.1007/s00210-006-0092-z

[39] Gefvert, O., Eriksson, B., Persson, P., Helldin, L., Björner, A., Mannaert, E., Remmerie, B., Eerdekens, M. and Nyberg, S. (2005) Pharmacokinetics and $\mathrm{D}_{2}$ receptor occupancy of long-acting injectable risperidone (Risperdal Consta) in patients with schizophrenia. International Journal of Neuropsychopharmacology, 8, 27-36. doi:10.1017/S1461145704004924

[40] Kapur, S. and Seeman, P. (2001) Does fast dissociation from the dopamine $\mathrm{D}_{2}$ receptor explain the action of atypical antipsychotics? A new hypothesis. American Journal of Psychiatry, 158, 360-369. doi:10.1176/appi.ajp.158.3.360

[41] Baron, J.C., Martinot, J.L., Cambon, H., Boulenger, J.P., Poirier, M.F., Caillard, V., Blin, J., Huret, J.D., Loc'h, C. and Maziere, B. (1989) Striatal dopamine receptor occupancy during and following withdrawal from neuroleptic treatment: Correlative evaluation by positron emission tomography and plasma prolactin levels. Psychopharmacology, 99, 463-472. doi:10.1007/BF00589893

[42] Farde, L. and Nordstrom, A.L. (1992) PET analysis indicates atypical central dopamine receptor occupancy in clozapine-treated patients. British Journal of Psychiatry, 17, 30-33. 